\title{
Analysis on the Challenges and Countermeasures of Talent Training in Higher Vocational Education
}

Lin Lv

Media Academy, Jilin Engineering Normal University, Changchun 130052, Jilin, China.

Abstract: With the advancement of social and economic development and educational reform, some problems faced by higher vocational education have gradually emerged. At the same time, as an important part of urbanization construction, higher vocational education also faces many challenges. In order to adapt to the current educational development situation, it is necessary to seize opportunities, meet challenges, reform the ways of talent training in higher vocational education, deeply explore talent training models, and propose effective solutions and programs for education development and talent training.

Keywords: Higher Vocational Education; Talent Training; Challenge; Countermeasures;

In recent years, the development of information technology, especially the popularization of the Internet, has posed a very severe challenge to higher education. The type of education has changed from traditional elite education to popular education. In addition, the development of urbanization requires a large amount of high-quality human resources as support. As a training base for high-quality talents, higher education shoulders the glorious mission of cultivating highskilled talents for the frontline needs of social production and construction. However, in the process of development, due to the limitations of the system and its own factors, many problems have gradually been exposed. Therefore, reforming the current higher education talent training model is the first step that higher education needs to take to keep up with the development of the times.

\section{Analysis of challenges faced by talent training in higher vocational education}

\subsection{University talents are "excluded" by artificial intelligence}

The application of artificial intelligence in modern economic development will undoubtedly affect the structure of labor demand. As far as the current situation of higher vocational education is concerned, students are more likely to be replaced in terms of technology mastery compared with artificial intelligence. As we all know, the use of Foxconn robots in the factory has forced tens of thousands of workers to lose their jobs. In the future, Foxconn will still replace the traditional worker mode with no less than 10,000 machines per year. Although there are certain defects in artificial intelligence work, large-scale applications will save more labor costs and increase production. The promotion of scientific research will also greatly improve its performance. This will form a crowding effect on vocational education and the social labor force cultivated. Large quantities of skilled labor for college graduates People will also face the challenge of employment.

\subsection{Traditional talent training programs are backward}

In traditional higher vocational education talent training, there are often many theoretical courses, unsystematic curriculum construction, and untimely updating of teaching materials, which seriously affect talent training. The main reason is that higher vocational education started late, and there is no clear concept and positioning, which leads to people's prejudice against this level of education, which is considered to reduce the difficulty of ordinary higher Copyright @ 2020 Lin Lv

doi: $10.18282 /$ le.v9i7.1461

This is an open-access article distributed under the terms of the Creative Commons Attribution Non-Commercial License

(http://creativecommons.org/licenses/by-nc/4.0/), which permits unrestricted non-commercial use, distribution, and reproduction in any medium, provided the original work is properly cited. 
education. There are also some colleges and universities that regard higher vocational education as a popular education, and the enrollment does not consider student skills, and the knowledge and skills of students admitted are relatively single. In addition, there is a lack of systematic curriculum construction, the content of teaching materials is not updated in time, and the traditional content cannot meet the teaching requirements of current social development, which leads to a disconnect between student learning and social development.

\subsection{Serious lack of humanistic quality training}

People take higher education as skills education by default, which is highly targeted in teaching, focusing on the cultivation of students' professional skills, and neglecting the cultivation of students' humanistic qualities. Under this kind of educational thinking, it will inevitably lead to students' humanities. The lack of knowledge in quality, such as outlook on life, values, moral level and psychological quality, cannot be fully developed. Even if the students trained in this way of lowering moral education standards and simply improving skills have higher skills, their overall quality will seriously affect the students' progress in social development, and ultimately cannot adapt to the social rhythm.

\section{Higher vocational education personnel training reform measures}

\subsection{Using artificial intelligence to cultivate high-end talents}

In the process of the popularization and application of artificial intelligence, the production workshops of many companies will gradually realize informatization, intelligence and digitization. The talents sought after in the future labor market must be senior technicians who can operate intelligent systems and maintain intelligent equipment. For this reason, higher vocational education needs to innovate itself in the process of talent training, upgrade teaching equipment, design teaching models with the integration of artificial intelligence technology and big data technology, and enhance the citation and application of related materials of big data systems. At the same time, the development of artificial intelligence can also promote the realization of human-computer interaction. Teachers can use humancomputer interaction in teaching design to achieve the unity of theory and practice teaching, and use electronic equipment to explain and learn theoretical knowledge, making students more intuitive Feeling the impact of knowledge, learning efficiency will also be greatly improved.

\subsection{Improve the traditional talent training program}

Strengthening the construction of the curriculum system, improving the teaching content, increasing the proportion of high-tech applications in the teaching content, and strengthening the application training of the curriculum content is the focus of the reform of the talent training program. First of all, if higher vocational education wants to increase the intake of high-tech content, it needs higher vocational colleges to adapt to the society's demand for skilled talents, keep up with the pace of social development, through school-enterprise cooperation or strengthen communication between the same industry The way to adjust the curriculum and teaching content of colleges and universities will not only allow students to master the basic knowledge of the professional field, but also need to master the mainstream skills of the professional field. In addition, it is necessary to strengthen the applicability of the content of the teaching course. In the course of teaching, abandon the traditional teaching method of introducing theoretical knowledge, explain the application of knowledge in a deeper level, strengthen the training of students on applied knowledge, and improve students' skills Level of mastery. At the same time, higher vocational colleges need to pay attention to the planning and construction of teaching materials, develop practical teaching materials in school-enterprise cooperation, and research compound teaching materials that meet teaching needs. This can not only reduce the duplication of teaching materials, but also change traditional teaching. The scattered and disordered content has laid a solid foundation for the cultivation of high-tech professionals.

\subsection{Strengthen the cultivation of humanistic quality in higher vocational education}

The traditional higher vocational education has a single teaching structure, and the trained single-skilled talents cannot meet the development needs of modern society. In response to this phenomenon, it is necessary to reform the teaching structure of higher vocational colleges. Therefore, in terms of talent training, a scientific talent training plan can be formulated by combining the training specifications of the corresponding major of the school and the comprehensive 
consideration of students' abilities. For vocational students, it is necessary to decompose the vocational positions in this industry, delimit professional-related positions, and then summarize all the positions to help students find the direction of employment and future development in the process of researching these positions The positioning of the school is to increase the employment rate of the school while improving the future development level of students; for students in technical positions, through a comprehensive analysis of their knowledge, technology, ability and quality, the job knowledge, ability and quality requirements are decomposed, and then summarized and integrated. According to different professional needs, all professional courses are sorted to form specific training programs for each professional. In the process of targeted training, humanistic quality training is added to improve students' values and moral standards, enhance students' psychological quality and the ability to bear things, so as to cultivate a group of high-skilled and highquality technical talents. In order to better meet the needs of the society for talent development.

\subsection{Combination of industry and education promotes the reform of talent training methods}

The integration of industry and education to promote the integration of industry and education is an effective way to ensure that the talents cultivated in higher vocational colleges meet the requirements of society. First, according to the changes in the social situation and the industry's requirements for talents, the professional settings in higher vocational education need to be innovated, and new majors should be added on the basis of traditional majors. Secondly, teachers need to consult senior people in the social field and related industries for students. Put forward reasonable suggestions for the needs of technological development and capacity development, and train students in a targeted manner; again, strive for government funding support, contact enterprises to provide scientific research bases for teachers, and allow teachers and enterprise technicians to cooperate and jointly develop new technologies, To step on a broad road for the training of high-skilled talents in schools, promote the training of talents in higher vocational colleges, and promote the long-term development of higher vocational education.

\section{Conclusion}

In short, the development of higher vocational education needs to follow the pace of modernization, keep up with the pace of Internet technology development, abandon the traditional teaching model with low effectiveness in traditional education, and innovate and reform traditional teaching methods to adapt them to modern teaching equipment Requirements for teaching. Secondly, it is necessary to increase the construction of the faculty of masters, improve the level of teacher skills, and gradually increase the practical ability of teachers through school-enterprise cooperation, so as to better promote the development of students in this field. Of course, technological investment and innovation require a large amount of funds as backup support to achieve leapfrog development of education and promote the cultivation of highly skilled talents without government support and capital investment. Facing the challenges and foundations of the new era, higher vocational education needs to intensify reforms, innovate continuously, seize opportunities, and meet challenges, so as to provide strong support for the cultivation of high-skilled talents in our country.

\section{References}

1. He H. The transformation and development of higher vocational education under the background of "large enrollment".[J] Adult Education, 2020, 40(1): 71-74.

2. Han Z, Han K. The transformation of higher vocational education talent training model in the artificial intelligence era: opportunities, challenges and paths[J]. Technoeconomics, 2019, 38(9): 84-88.

3. Yang Y. Deepening reform and innovative development of higher vocational education under the background of the new era[J]. Education and Vocation, 2019, (13): 28-35.

4. Du R, Jiang K. Challenges and opportunities brought by the leapfrog development of artificial intelligence to vocational education [J]. Continuing Education Research, 2018, (5): 51-54.

5. Liu G, Song T. Discussion on the Development Trend of Higher Vocational Education in the "Internet+" Era[J]. Journal of Taiyuan Urban Vocational and Technical College, 2019, (5): 1-3.

6. Wu K. Analysis on the practice of deep integration of vocational education and employee training[J]. Silk Road Vision, 2018, (26): 33, 35 . 